\title{
PENGEMBANGAN MEDIA AUDIO VISUAL KISAH ULUL AZMI PADA MATA PELAJARAN AL-ISLAM UNTUK MENINGKATKAN HASIL BELAJAR
}

\author{
Hafidh Nur Fauzi \\ E-mail: hafidhnurfauzi90@gmail.com \\ Mahasiswa Program Studi Magister Pendidikan Agama Islam \\ Universitas Ahmad Dahlan Yogyakarta \\ Istiqomah \\ E-mail: is.istiqomah17@gmail.com \\ Mahasiswa Program Studi Pendidikan Guru Madrasah Ibtidaiyah \\ STPI Bina Insan Mulia Yogyakarta
}

\section{Abstrak}

Rendahnya minat belajar dan hasil belajar peserta didik yang rendah adalah masalah dalam pembelajaran Al-Islam pada materi Kisah Rasul Ulul Azmi. Salah satu solusi pengembangan media audio visual untuk meningkatkan hasil belajar peserta didik, mengunakan Research and Development model Borg and Gall. Analisis data dengan bentuk pre-test dan post-test dengan perbandingan hasil belajar sebelum dan sesudah pemakaian media audio visual. Hasil ujicoba ahli materi I dengan 98,9\% kategori sangat baik, ahli materi II dengan 95,8\% kategori sangat baik, ahli media I dengan 79,8\% kategori baik, ahli media II dengan 90,6\% kategori sangat baik, uji coba orang dengan 95,6\% kategori sangat baik, evaluasi kelompok kecil 89,5\% kategori baik sekali, uji coba lapangan 96,8\% kategori sangat baik, media dinyatakan layak. Hasil uji keefektifan media audio visual dengan analisis data dengan $t_{\text {hitung }}(3,04)>t_{\text {tabel }}(2,22)$, disimpulkan bahwa pembelajaran dengan media audio visual kisah Ulul Azmi dapat meningkatkan hasil belajar peserta.

\section{Kata kunci: Pengembangan, Audio Visual, Ulul Azmi, Hasil Belajar}

\section{Abstract}

The low interest in learning and low learning outcomes of students is a problem in Al-Islamic learning in the material of the Story of the Apostle Ulul Azmi. One solution for developing audio visual media is to improve student learning outcomes, using the Research and Development model of Borg and Gall. Data analysis with the form of pre-test and post-test with a comparison of learning outcomes before and after the use of audio-visual media. The 
Hafidh Nur Fauzi, Istiqomah : Pengembangan Media Audio Visual Kisah Ulul Azmi Pada Mata Pelajaran Al-Islam Untuk Meningkatkan Hasil Belajar

material expert I trial results with $98.9 \%$ very good category, material experts II with $95.8 \%$ very good category, I media expert with $79.8 \%$ good category, II media expert with $90.6 \%$ very good category, test try people with $95.6 \%$ very good category, small group evaluation $89.5 \%$ very good category, $96.8 \%$ field trial category is very good, media is declared feasible. The test results of the effectiveness of audio-visual media with data analysis with t_count (3.04)> t table (2.22), concluded that learning with the audio visual media of the Ulul Azmi story can improve the learning outcomes of participants.

\section{Keywords: Development, Audio Visual, Ulul Azmi, Learning Outcomes}

\section{A. PENDAHULUAN}

Dari hasil observasi awal yang dilakukan oleh peneliti di SD Muhammadiyah Pendowoharjo Sewon Bantul merupakan sekolah yang secara geografis letaknya dipedesaan. Keadaan tersebut tentunya membuat SD Muhammadiyah Pendowoharjo Sewon Bantul mengalami keterbatasan dalam penggunaan media dalam proses pembelajaran dikelas. Terutama pada mata pelajaran Al-Islam tentang "Kisah Rasul Ulul Azmi" pendidik hanya mengandalkan buku paket dan Lembar Kerja Siswa (LKS) sebagai penunjang sumber belajar dalam proses belajar mengajar dikelas.

Permasalahan yang terjadi pada mata pelajaran Al-Islam yaitu peserta didik kelas $\mathrm{V}$ memiliki keterbatasan dalam menceritakan kembali tentang kisah kehidupan rasul yang mendapatkan gelar Ulul Azmi. Peserta didik juga mengalami kesulitan dalam memahami sejarah kehidupan rasul Ulul Azmi serta mengambil hikmah yang terkandung dari kisah perjalanan hidup yang penuh dengan pelajaran. Selain itu pendidik pengampu mata pelajaran juga belum mampu dalam 
Hafidh Nur Fauzi, Istiqomah : Pengembangan Media Audio Visual Kisah Ulul Azmi Pada Mata Pelajaran Al-Islam Untuk Meningkatkan Hasil Belajar

mendramatisasikan kisah kehidupan rasul Ulul Azmi untuk memberikan kesan imajinasi kepada peserta didik.

Hal ini mengakibatkan peserta didik kelas $\mathrm{V}$ tidak memperhatikan pendidik saat pembelajaran pada mata pelajaran Al-Islam sedang berlangsung. Sehingga menjadikan proses belajar mengajar terhambat dan peserta didik menjadi kurang aktif. Pernyataan ini dibuktikan dengan data hasil belajar yang diperoleh peserta didik kelas $\mathrm{V}$ mata pelajaran Al-Islam pada materi Kisah Rasul Ulul Azmi menunjukan bahwa nilai yang dicapai $70 \%$ peserta didik masih dibawah batas Kriteria Ketuntasan Minimal (KKM) yaitu 75.

Berdasarkan permasalahan diatas maka perlu dikembangkan media audio visual pembelajaran Al-Islam dengan materi pokok Kisah Rasul Ulul Azmi di SD Muhammadiyah Pendowoharjo. Alasan memakai media audio visual adalah dapat diputar kembali secara berulang. Sehingga bagi peserta didik yang yang belum memahami alur cerita Kisah Rasul Ulul Azmi dapat mengulang materi kembali. Media audio visual mampu mempengaruhi secara suasana dan perilaku melalui efek suara, latar dan gambar video. Sehingga peserta didik lebih antusias dalam mengikuti dan memperhatikan pelajaran Al-Islam. Media audio visual dapat membangkitkan imajinasi peserta didik. Sehingga memudahkan pendidik dalam mengatasi keterbatasan memberi daya imajinasi dan pusat perhatian.

\section{B. PEMBAHASAN}

1. Pengembangan Media Pembelajaran

Pengembangan adalah proses yang digunakan untuk mengembangkan dan memvalidasi produk pendidikan baik 
Hafidh Nur Fauzi, Istiqomah : Pengembangan Media Audio Visual Kisah Ulul Azmi Pada Mata Pelajaran Al-Islam Untuk Meningkatkan Hasil Belajar

berupa proses, produk maupun rancangan. ${ }^{30}$ Sedangkan media adalah segala sesuatu yang dapat dipergunakan dalam menyalurkan pesan dari pengirim ke penerima sehingga dapat merangsang pikiran, perasaan, minat serta perhatian peserta didik sedemikian rupa sehingga terjadi proses belajar mengajar. ${ }^{31}$ Dengan demikian pengertian pengembangan media adalah suatu proses yang dipakai dalam mengembangkan sebuah produk dengan memberikan stimulus kepada peserta didik dalam proses pembelajaran.

Dalam suatu pembelajaran dibutuhkan hubungan komunikasi yang baik antara pendidik dan peserta didik untuk meningkatkan hasil pembelajaran yang optimal. Sehingga proses pembelajaran dapat berjalan dengan baik dan efektif. Interaksi yang dilakukan oleh pendidik kepada peserta didik umumnya sebatas komunikasi ceramah konvensional. Akan tetapi apabila tidak diimbangi dengan menggunakan alat bantu mengajar (media) maka peserta didik akan mengalami keterlambatan dalam menerima materi. Berbeda halnya apabila ceramah konvensional dikombinasikan dengan penggunaan media maka akan meningkatkan hasil belajar peserta didik secara signifikan. ${ }^{32}$

a. Jenis-jenis Media Pembelajaran

Taksonomi media berdasarkan rancangan pembelajaran terdiri atas berbagai macam pendekatan.

30 Punaji Setyosari. Metode Penelitian Pendidikan dan Pengembangan (Jakarta: Paramedia Group, 2013), hal. 277

31 Arif S. Sadiman. Media Pendidikan Pengertian, Pengembangan dan Pemanfaatannya (Jakarta: Rajagrafindo Persada, 2011), hal. 7

32 Beni Harsono, dkk. Perbedaan Hasil Belajar Antara Metode Ceramah Konvensional dengan Ceramah Berbantuan Media Pada Pembelajaran. (Jurnal PTM, Volume 9, Nomor 2, 2009), hal. 71 
Hafidh Nur Fauzi, Istiqomah : Pengembangan Media Audio Visual Kisah Ulul Azmi Pada Mata Pelajaran Al-Islam Untuk Meningkatkan Hasil Belajar

Media juga dapat dibagi jenisnya berdasarkan indera. Klasifikasi media berdasarkan indera ini terdiri atas:

1) Media Audio

Media audio adalah media yang hanya melibatkan indera pendengar dan hanya mampu memanipulasi kemampuan suara semata. Dilihat dari sifat pesan yang diterimanya media audio ini menerima pesan verbal dan non verbal. Pesan verbal seperti bahasa lisan, dan bahasa non verbal seperti bunyi-bunyian. Contoh: disk recording, tape, dan compact disk.

2) Media Visual

Media visual adalah media yang hanya melibatkan indera penglihatan. Termasuk dalam jenis media cetak verbal, media cetak grafis, dan media non cetak. Media visual adalah media yang memuat pesan visual (pesan linguistic tertulis), pesan visual non verbal (sketsa, gambar, lukisan, photo) dan media visual non verbal tiga dimensi (miniature, mock up, specimen, diorama).

3) Media Audio Visual

Media audio visual adalah media yang melibatkan indera pendengaran dan penglihatan sekaligus dalam satu proses. Sifat pesan yang dapat disalurkan melalui media dapat berupa pesan verbal dan non verbal yang terlihat layaknya media visual juga pesan verbal media audio. Pesan audio visual yang terlihat seperti film, dokumenter, drama, video, televisi.

4) Multimedia

Multimedia adalah media yang melibatkan berbagai indera dalam sebuah proses pembelajaran. Termasuk dalam media ini adalah segala sesuatu yang 
Hafidh Nur Fauzi, Istiqomah : Pengembangan Media Audio Visual Kisah Ulul Azmi Pada Mata Pelajaran Al-Islam Untuk Meningkatkan Hasil Belajar

memberikan pengalaman secara langsung dapat melaui computer dan internet, bisa juga keterlibatan pengalaman. 33

b. Langkah Pengembangan Media Pembelajaran

Dalam mengembangkan suatu media pembelajaran perlu mempertimbangkan beberapa langkah dalam proses pembuatannya, yaitu:

1) Penyusunan Rancangan

Perencanaa yang teliti dengan menganalisis kebutuhan dan karakteristik peserta didik meliputi kemampuan, keterampilan, dan sikap peserta didik. Setelah analisis dilakukan dilanjutkan dengan merumuskan tujuan dan memberikan arah tujuan yang hendak dilakukan. Kemudian merumuskan alat pengukur tingkat keberhasilan yang sesuai dengan tujuan yang akan dicapai.

2) Penulisan

Dalam pokok materi instruksional yang telah ada sebelumnya, dalam sajian melalui media diawali dengan menuliskan naskah/prototype materi. Setelah itu akan didapat treatment tentang gambaran materi secara berurutan. Barulah masuk pada tahapan produksi media.

3) Produksi Media

Memproduksi media yang sebelumnya telah dirancang dan siap disajikan dan diujicobakan kepada peserta didik guna menyelesaikan permasalahan dalam pembelajaran yang telah ditemukan diawal penelitian.

33 Yudi Munadi. Media Pembelajaran. (Jakarta: Referensi Group, 2013), hal. 55-57

34 Jurnal Komunikasi dan Pendidikan Islam, Volume 8, Nomor 1, Juni 2019 
Hafidh Nur Fauzi, Istiqomah : Pengembangan Media Audio Visual Kisah Ulul Azmi Pada Mata Pelajaran Al-Islam Untuk Meningkatkan Hasil Belajar

4) Evaluasi Media

Evaluasi dilakukan utuk mengetahui apakah media yang dibuat tersebut dapat menjawab dan mencapai tujuan yang telah ditetapkan atau tidak. ${ }^{34}$

2. Media Audio Visual

Media audio visual adalah gabungan dari audio dan visual. Audio adalah suara yang dapat didengar dan visual adalah gambar yang dapat dilihat. Media audio visual dapat didefinisikan sebagai media intruksional modern yang sesuai dengan perkembangan zaman atau kemajuan ilmu pengetahuan dan teknologi yang meliputi media yang dapat dilihat, didengar dan campuran keduanya. ${ }^{35} \mathrm{Hal}$ ini diperjelas oleh Syaiful Bahri yang menyebutkan bahwa media audio visual merupakan media yang memiliki unsur-unsur suara dan gambar. ${ }^{36}$

Menurut Azhar Arsyad media audio visual adalah cara menghasilkan atau menyajikan materi kepada peserta didik dengan menggunakan mesin mekanis dan elektronik untuk menyampaikan pesan audio dan visual. ${ }^{37}$ Dengan demikian dapat disimpulkan bahwa media audio visual adalah media yang tersusun dari unsur audio dan visual yang digunakan sebagai perantara untuk menyampaikan konsep, gagasan dan pengalaman yang ditangkap oleh indera pendengaran dan pandangan sehingga memudahkan peserta didik dalam memahami konten isi materi.

34 Ibid., hal. 99

35 Ahmad Rohani. Media Instruksional Education. (Jakarta: Rineka Cipta, 1997), hal. 298

36 Syaiful Bahri \& Aswin Zain. Strategi Belajar Mengajar. (Jakarta: Ciputat Press, 2007), hal. 141

37 Azhar Arsyad. Media Pengajaran. (Jakarta: Raja Grafindo Persada, 2002), hal. 89 
Hafidh Nur Fauzi, Istiqomah : Pengembangan Media Audio Visual Kisah Ulul Azmi Pada Mata Pelajaran Al-Islam Untuk Meningkatkan Hasil Belajar

a. Keuntungan menggunakan media audio visual

1) Dapat menyajikan berbagai jenis bahan termasuk gambar, film, dan drama.

2) Menyajikan sajian konkrit dan jelas bagi peserta didik.

3) Dapat menghadirkan dunia nyata kedalam kelas seperti kisah atau peristiwa yang terjadi.

4) Dapat memberikan stimulus kepada peserta didik untuk meihat dan mendengar peristiwa atau materi yang disampaikan. ${ }^{38}$

b. Kelemahan menggunakan media audio visual

1) Hanya menyajikan komunikasi satu arah.

2) Pendidik kesulitan dalam mengatur kesempatan dalam memetakan dan memahami kempuan individu peserta didik. 39

3. Ulul Azmi

Kata Ulu Al-'Azmi terdiri dari dua suku kata, yaitu ulu dan 'azmi. Dalam bahasa Arab bermakna $d z u^{40}$ yang jika dialih kedalam bahasa Indonesia berarti yang empunya. ${ }^{41}$ Sedangkan 'azm dalam bahasa Arab bermakna sabar dan sungguh-sungguh. ${ }^{42}$ Definisi lain adalah al-Azimah (ketetapan hati) artinya adalah apa yang engkau teguhkan di dalam hati dari suatu perkara. 'Azm juga berarti kekuatan

38 Nasution. Teknologi Pendidikan. (Bandung: Sinar Baru, 1990), hal. 30

39 Fatah Syukur. Teknologi Pendidikan. (Semarang: Rasail Media Group, 2008), hal. 145

40 Ibrahim Mustafa, Ahmad az-Ziyyat, dkk. Mu'jam al-Wasith: Majma' alLughah al-'Arabiyah bil Qahirah. (Kairo: Maktabah as-Syaruq ad-Dauliyah, 2005), cet. 2 , hal. 23

41 A.W. Munawwir. Kamus al-Munawwir Arab-Indonesia. (Surabaya: Pustaka Progressif, 1997), cet. 14, hal. 454

42 Ibrahim. Ibid., hal 599 
Hafidh Nur Fauzi, Istiqomah : Pengembangan Media Audio Visual Kisah Ulul Azmi Pada Mata Pelajaran Al-Islam Untuk Meningkatkan Hasil Belajar

atas sesuatu dan sanggup bersabar diatasnya. ${ }^{43}$ Ulul Azmi adalah orang yang memiliki keteguhan dan ketetapan hati. ${ }^{44}$

Secara makna istilah Ulul Azmi adalah ulul hazm, yaitu orang yang sabar terhadap barbagai macam perkara dan dia tetap teguh dalam menghadapinya. ${ }^{45}$ Pendapat lain mendefinisikan Ulul Azmi adalah orang-orang yang memikul beban dan sabar atas apa yang mereka alami dari siksaan kaumnya yang menentang akan hidayah yang mereka sampaikan. ${ }^{46}$ Dari uraian diatas dapat disimpulkan bahwa gelar Ulul Azmi adalah diberikan kepada Rasul dan Nabi karena ketabahan dan keteguhan mereka dalam berdakwah mengajak umatnya dalam rangka menyembah Allah SWT. ${ }^{47}$

a. Para Nabi dan Rasul yang bergelar Ulul Azmi

Jumhur (mayoritas) ulama berpendapat mengenai nabi dan rasul yang mendapat gelar Ulul Azmi hanya lima orang. Imam Al-Thabarsi menjelaskan didalam sebuah tafsirnya mengenai Ulul Azmi, beliau memaparkan bahwa maksud dari kata Ulul Azmi adalah para rasul yang datang dengan membawa syariat tersendiri yang mengganti syariat rasul terdahulu. Mereka adalah Nuh

43 Syihabbudin Ahmad bin Ahmad Umar al-Khafaji al-Mishri. Hasyi'ah asSyi'ahab 'Ala Tafsir al-Baidhawi. (Beirut: Dar Shadir, 1998), jilid 8, hal. 37

44 Muhammad bin Ali bin Abdullah as-Syaukani al-Yamani. Fathul alQadir. (Damaskus: Dar Ibnu Katsir, 1994), cet. 1, jilid. 5, hal. 32

45 Ahmad bin Ibrahim as-Samarqandi. Bahrul Ulum. (CD. Maktabah Syamilah, 3.47), jilid. 3, hal. 294

46 Mahyuddin bin Muhammad Musthofa. I'rab Al-Qur'an wa Bayanuhu. (Beirut: Dar Ibnu Katsir, 1995), Cet. 4, Jilid. 9, hal. 23

47 Dikdasmen PP Muhammadiyah. Pendidikan Al-Islam SD Muhammadiyah. (Yogyakarta: Gramasurya, 2018), hal. 158 
Hafidh Nur Fauzi, Istiqomah : Pengembangan Media Audio Visual Kisah Ulul Azmi Pada Mata Pelajaran Al-Islam Untuk Meningkatkan Hasil Belajar

As, Ibrahim As, Musa As, Isa As dan Muhammad SAW. ${ }^{48}$ Pendapat serupa juga dunukil oleh Al-Baghowi. 49

Pendapat diatas sama dengan riwayat Ibnu Abbas (w. $68 \mathrm{H}$ ) dan Qatadah (w. $23 \mathrm{H}$ ) yang mengatakan bahwa mereka adalah Nuh, Ibrahim, Musa, Isa dan mereka bersama Rasulullah SAW sebagai orang yang diberikan tugas mengemban syariat. Kelima orang ini Allah SWT sebutkan secara khusus dalam surat Al-Ahzab dan AsSyura ${ }^{50}$ sebagai berikut:

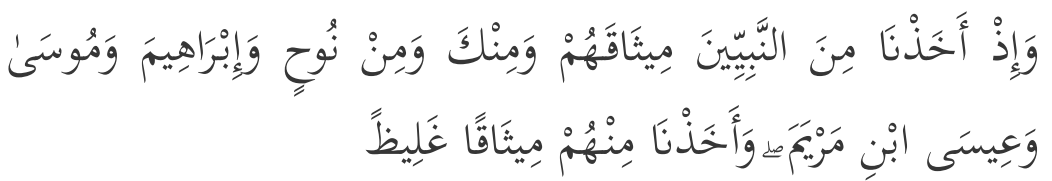

Artinya:

"Dan (ingatlah) ketika Kami mengambil perjanjian dari nabi-nabi dan dari kamu (sendiri) dari Nuh, Ibrahim, Musa dan Isa putra Maryam, dan Kami telah mengambil dari mereka perjanjian yang teguh." (QS. Al-Ahzab: 7)

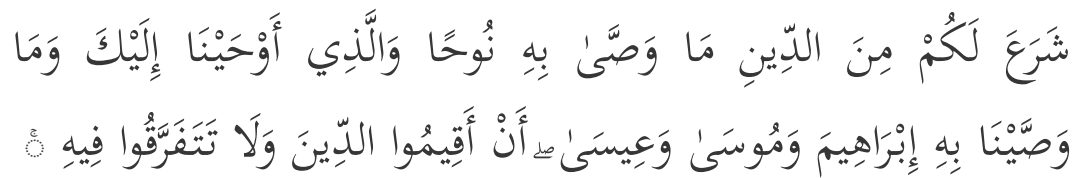

Artinya:

"Dia telah mensyari'atkan bagi kamu tentang agama apa yang telah diwasiatkan-Nya kepada Nuh dan apa yang telah Kami wahyukan kepadamu dan apa yang telah Kami wasiatkan kepada Ibrahim, Musa dan Isa yaitu: Tegakkanlah agama dan janganlah kamu berpecah belah tentangnya..." (QS. As-Syura: 13)

\section{1, hal. 287}

48 At-Thusi. Al-Tibyan. (Maktabah Al-A'lam Al-Islami, 1891), Cet. 1, Jilid.

49 Muhammad bin Alauddin. Syarah Thawiyah. (Beirut: Muassasah arRisalah, 1997), Cet. 10, Jilid. 2, hal. 424.

50 Alauddin Ali bin Muhammad bin Ibrahim bin Umar as-Syaihi Abu alHasan. Lubabu at-Ta'wil fi Ma'ani at-Tanzil. (Beirut: Dar al-Fikr, 1979), Cet.1, Jilid. 4, hal. 138 
Hafidh Nur Fauzi, Istiqomah : Pengembangan Media Audio Visual Kisah Ulul Azmi Pada Mata Pelajaran Al-Islam Untuk Meningkatkan Hasil Belajar

Dari penjelasan di atas disimpulkan bahwa nabi dan rasul yang mendapatkan gelar Ulul Azmi karena kesabaran dan keteguhannya dalam berdakwah kepada kaumnya berjumlah lima orang. Yaitu adalah Nabi Nuh As, Nabi Ibrahim As, Nabi Musa As, Nabi Isa As dan Nabi Muhammad SAW. Dalam prektek pembelajaran dikelas peserta didik lebih familiar menyingkat nama kelima rasul Ulul Azmi tersebut dengan singkatan "NIMIM”. Hal ini juga untuk memudahkan peserta didik didalam mengingat dan menghafalkannya.

4. Hasil Belajar

Hasil belajar merupakan perubahan tingkah laku dari proses pembelajaran yang mencakup ranah kognitif, afektif dan psikomotor. ${ }^{51}$ Hasil belajar merupakan hasil dari interaksi tindak belajar dan tindak mengajar. Dari guru tindak mengajar diakhiri oleh evaluasi, sementara dari peserta didik adalah hasil belajar. ${ }^{2}$ Benyamin Bloom mengemukakan secara garis besar membagi hasil belajar menjadi tiga ranah, yaitu ranah koqnitif, ranah afektif dan ranah psikomotorik.

a. Ranah Kognitif

Ranah Kognitif Berkenaan hasil belajar intelektual yang terdiri dari enam aspek. Yaitu Pengetahuan, Pemahaman, Aplikasi, Analisis, Sintesis, dan Evaluasi.

b. Ranah Afektif

Ranah Afektif berkenaan dengan sikap dan nilai yang terdiri dari lima aspek yaitu: Receiving/Penerimaan,

51 Nana Sudjana. Penilaian Hasil Proses Belajar Mengajar. (Bandung: Remaja Rosdakarya, 2009), hal. 3

52 Dimyati \& Mujiono. Belajar dan Pembelajaran. (Jakarta: Rineka Cipta, 2006), hal. 6 
Hafidh Nur Fauzi, Istiqomah : Pengembangan Media Audio Visual Kisah Ulul Azmi Pada Mata Pelajaran Al-Islam Untuk Meningkatkan Hasil Belajar

responding/jawaban, valuing/penilaian, organisasi, karakteristik nilai/internalisasi nilai.

c. Ranah Psikomotorik

Hasil belajar psikomotor tampak dalam bentuk keterampilan (skill) dan kemampuan bertindak individu. ${ }^{53}$

Dari beberapa pendapat diatas dapat disimpulkan bahawa hasil belajar adalah penilaian hasil yang sudah dicapai peserta didik dalam ranah koqnitif, afektif dan psikomotor yang diperoleh sebagai akibat dari usaha kegiatan belajar yang dinilai dalam periode tertentu.

5. Pengembangan Media Audio Visual Kisah Rasul Ulul Azmi

Pengembangan ini menggunakan model pengembangan Borg and Gall dalam melaksanakan pengembangan media audio visual pembelajaran. Dengan mengunakan 10 langkah prosedur pengembangan. ${ }^{4}$ Adapun tahapan yang harus dilakukan dalam pengembangan media audio visual ini adalah sebagai berikut:

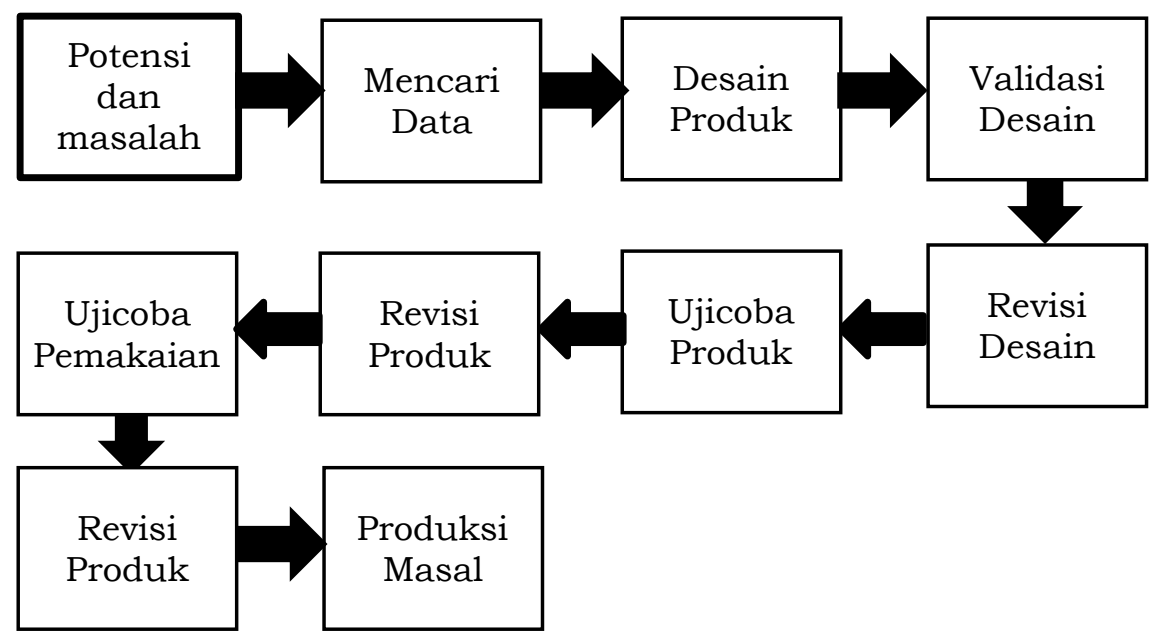

53 Benjamin Bloom S. Taxonomy of Educational: The Classification of Educational Goals, Handbook I Cognitive Domain. (New York: Longman Inc Green and Co, 1956), hal 56

54 Borg W.R \& Gall M.D. Educational Research: An Introduction. (London: Longman Inc, 2003), hal. 87 
Hafidh Nur Fauzi, Istiqomah : Pengembangan Media Audio Visual Kisah Ulul Azmi Pada Mata Pelajaran Al-Islam Untuk Meningkatkan Hasil Belajar

Alasan menggunakan model pengembngan diatas adalah model pengembangan Borg and Gall merupakan model pengembangan sebagai acuan utama bagi penelitian pengembanga dan memiliki sistematika dari awal hingga akhir yang cukup baik. Sehingga model pengembangan Borg and Gall ini cocok untuk mengembangkan media audio visual Kisah Rasul Ulul Azmi dalam pembelajaran Al-Islam kelas V di SD Muhammadiyah Pendowoharjo Sewon Bantul.

a. Langkah Pengembangan Media

1) Potensi dan Masalah

Potensi merupakan segala susuatu yang apabila didayagunakan akan mempunyai nilai tambah. Sedangkan masalah adalah penyimpangan antara yang diharapkan dengan yang terjadi. ${ }^{55}$ Dalam praktiknya masalah dalam penelitian bisa muncul dari isu-isu, kesulitan-kesulitan dan perilaku-perilaku. ${ }^{56}$ Dengan ditemukannya masalah atau isu maka langkah selanjutnya akan menuntun peneliti kepada signifikansi penelitian ketahapan selanjutnya.

Berdasarkan wawancara dengan salah seorang Pendidik di SD Muhammadiyah Pendowoharjo yang mengampu mata pelajaran Al-Islam yang ditemui oleh peneliti dilapangan menemukan bahwa sebagian besar peserta didik menyukai pembelajaran dengan pemutaran video karena lebih tidak membosankan, namun ditemukan pula masalah bahwa peserta didik

55 Sugiyono. Metode Penelitian dan Pengembangan RnD. (Bandung: Alfabeta, 2017), hal. 409-410

56 John W. Creswell. Research Design. (Yogyakarta: Pustaka Pelajar, 2017), hal 154 
Hafidh Nur Fauzi, Istiqomah : Pengembangan Media Audio Visual Kisah Ulul Azmi Pada Mata Pelajaran Al-Islam Untuk Meningkatkan Hasil Belajar

merasa terlena dengan pemutaran video sehingga pembelajaran kurang interaktif.

2) Mencari Data

Metode penelitian yang digunakan disini adalah dengan melakukan pengamatan langsung dan wawancara tidak terstruktur. Wawancara tidak terstruktur dilakukan sebanyak tiga kali guna melengkapi data yang dibutuhkan.

3) Desain Produk

Pada tahapan ini, peneliti menyusun rancangan produk yang berupa media audio visual kisah rasul Ulul Azmi. Setelah melalui desain produk maka akan ditemukan produk awal yang akan dikembangkan.

4) Validasi Desain

Validasi desain produk dilakukan untuk mengetahui kelemahan dan kelebihan yang dimiliki oleh media audio visual kisah rasul Ulul Azmi tersebut dengan cara menghadirkan ahli atau pakar media yang sudah berkompeten untuk menilai produk yang dirancang tersebut.

5) Revisi Desain

Setelah desain produk media audio visual kisah rasul Ulul Azmi berhasil dan lulus validasi oleh para pakar dan ahli yang berkompeten maka akan diketahui kelemahannya. Kelemahan tersebut selanjutnya akan coba untuk diperbaiki ulang oleh peneliti sebelum nantinya masuk tahap selanjutnya.

6) Ujicoba Produk

Uji Coba Produk dilakukan untuk mengetahui secara awal mengenai kelemahan dan kelebihan yang 
Hafidh Nur Fauzi, Istiqomah : Pengembangan Media Audio Visual Kisah Ulul Azmi Pada Mata Pelajaran Al-Islam Untuk Meningkatkan Hasil Belajar dimiliki oleh media audio visual kisah rasul Ulul Azmi tersebut ketika diterapkan dilapangan.

7) Revisi Produk

Revisi produk dilakukan setelah produk yang berupa media audio visual kisah rasul Ulul Azmi diujiobakan kepada subjek dilapangan dalam skala kecil dan terbatas. Kemudian direvisi kembali agar produk pengembangan media layak untuk diterapkan kepada peserta didik dalam lingkup dan cakupan yang lebih luas dari sebelumnya.

8) Ujicoba Pemakaian

Setelah melewati beberapa tahapan dan diadakan pengujian terhadap produk dan dinyatakan layak. Maka langkah selanjutnya adalah ujicoba produk media audio visual kisah rasul Ulul Azmi untuk khalayak umum khususnya peserta didik.

9) Revisi Produk

Tahapan terakhir dalam revisi produk ini dilakukan jika dalam pemakaian dilingkup yang lebih luas terdapat kekurangan dan kelemahan sehingga dibutuhkan evaluasi yang bertujuan guna penyempurnaan produk media audio visual kisah rasul Ulul Azmi menjadi lebih terbaru lagi.

10) Produksi Masal

Pembuatan produk secara masal akan dilakukan apabila media audio visual kisah rasul Ulul Azmi telah diujicobakan dan dinyatakan layak digunakan dan diproduksi masal, maka peneliti memandang perlu untuk memproduksi media tersebut secara masal. Produksi masal ini bertujuan untuk 
Hafidh Nur Fauzi, Istiqomah : Pengembangan Media Audio Visual Kisah Ulul Azmi Pada Mata Pelajaran Al-Islam Untuk Meningkatkan Hasil Belajar

meningkatkan kualitas pembelajaran Sejarah Kebudayaan Islam.

b. Teknik Analisis Data

Teknik analisis pengumpulan data berhubungan erat dengan rumusan masalah yang duajukan guna menarik kesimpulan dari hasil penelitian. ${ }^{57}$ Data yang telah terkumpul dari penilaian dan tanggapan ahli materi, ahli media dan peserta didik selanjutnya akan diolah hingga merumuskan kesimpulan. Penilaian Aspek (PA) dihitung dengan rumus:

$$
\mathrm{PA}=\frac{\sum \text { jawaban terpilih aspek }}{\sum \text { jawaban ideal aspek }} \times 100
$$

Penilaian Seluruh Program (PSP) dihitung dengan rumus:

$$
\mathrm{PSP}=\frac{\sum \text { Presentase Aspek }}{\sum \text { Aspek }}
$$

Dengan kriteria hasil penilaian yaitu: 1) Nilai 4 (baik sekali) capaian 81-100\%,2) Nilai 3 (baik) capaian $61-80 \%$, 3) Nilai 2 (kurang) capaian 21-40\%. 4) Nilai 1 (kurang sekali) capaian $<21 \% .58$

c. Analisis Data Hasil Tes

Dalam menganalisis hasil belajar peserta didik dapat digunakan pre-test dan post-test maka rumusnya adalah:

$$
\begin{gathered}
\mathrm{Md}=\frac{\sum d}{N} \\
\sum x^{2}=\sum d^{2}-\left(\frac{\sum d}{N}\right)
\end{gathered}
$$

57 Suharsimi Arikunto. Prosedur Penelitian: Suatu Pendekatan Praktik. (Jakarta: Rineka Cipta, 2010), hal. 346

58 Artana Ketut Pegig \& Damajanti Kusuma Dewi. Evaluasi Media Pembelajaran. (Surabaya: Unesa Press, 2005), hal. 80 
Hafidh Nur Fauzi, Istiqomah : Pengembangan Media Audio Visual Kisah Ulul Azmi Pada Mata Pelajaran Al-Islam Untuk Meningkatkan Hasil Belajar

Hasil yang didapat selanjutnya dimasukan kedalam rumus:

$$
t=\frac{\mathrm{Md}}{\sqrt{\frac{\sum x^{2} d}{N(N-1)}}}
$$

Keterangan:

Md : Mean deviasi post-test dan pre-test.

Xd : Perbedaan deviasi dan mean deviasi

$\mathrm{N} \quad$ : Banyak subjek.

$\mathrm{df} / \mathrm{db}: \mathrm{N}-1^{59}$

d. Analisis Data

Tahapan dalam pelaksanaan produksi media pembelajaran audio visual kisah rasul Ulul Azmi untuk meningkatkan hasil belajar eserta didik di SD Muhammadiyah Pendowoharjo mulai dilakukan pada 2327 Desember 2018. Untuk mempermudah pendidik dan peserta didik dalam menggunakan media audio visual tersebut maka pengembang mengemasnya kedalam bentuk Compact Disk (CD) dan menyertakan buku panduan penggunaan.

Setelah pengembangan media audio visual kisah rasul Ulul Azmi untuk meningkatkan hasil belajar peserta didik melewati beberapa tahapan dan prosedur pengembangan maka diketahui beberapa angka data sebagai berikut: 
Hafidh Nur Fauzi, Istiqomah : Pengembangan Media Audio Visual Kisah Ulul Azmi Pada Mata Pelajaran Al-Islam Untuk Meningkatkan Hasil Belajar

\begin{tabular}{|l|l|l|}
\hline Evaluasi Ahli Materi I & $98,9 \%$ & Baik sekali \\
\hline Evaluasi Ahli Materi II & $95,8 \%$ & Baik sekali \\
\hline Evaluasi Ahli Media I & $79,8 \%$ & baik \\
\hline Evaluasi Ahli Media II & $90.6 \%$ & Sangat baik \\
\hline Evaluasi Perorang & $95,6 \%$ & Sangat baik \\
\hline Evaluasi Kelompok Kecil & $89,5 \%$ & Sangat baik \\
\hline Evaluasi Uji Lapangan & $96,8 \%$ & Sangat baik \\
\hline
\end{tabular}

Analisis Data Test

\begin{tabular}{|l|l|}
\hline Pre-Test & 670 \\
\hline Post-Test & 880 \\
\hline$D$ & 210 \\
\hline$D^{2}$ & 4700 \\
\hline
\end{tabular}

Data tersebut kemudian dianalisis sebagai berikut:

$$
\begin{aligned}
\operatorname{Md}=\frac{\sum d}{N} & =\frac{210}{11}=19,09 \\
\sum \mathrm{x}^{2} \mathrm{~d} & =\sum \mathrm{d}^{2-} \\
& =4700-\left(\frac{210}{11}\right)^{2} \\
& =4700-364,4281
\end{aligned}
$$

Kemudian data yang didapat dimasukan kedalam rumus t-test sebagai berikut:

$$
\begin{aligned}
t & =\frac{\mathrm{Md}}{\sqrt{\frac{\sum x^{2} d}{N(N-1)}}} \\
& =\frac{19,09}{\sqrt{\frac{4335,5719}{11(11-1)}}}
\end{aligned}
$$


Hafidh Nur Fauzi, Istiqomah : Pengembangan Media Audio Visual Kisah Ulul Azmi Pada Mata Pelajaran Al-Islam Untuk Meningkatkan Hasil Belajar

$$
\begin{gathered}
=\frac{19,09}{\sqrt{\frac{4335,5719}{110}}} \\
\quad=\frac{19,09}{\sqrt{39,41}}=\frac{19,09}{6,28}=3,04 \\
t=3,04
\end{gathered}
$$

Berdasarkan perhitungan diatas dengan taraf signifikansi $5 \% \mathrm{db}=11-1=10$. Sehingga diperoleh t 2,22 tabel yaitu ternyata $t$ hitung lebih besar dari t table yaitu $3,04>2,22$. Hal ini membuktikan bahwa terdapat perbedaan yang signifikan pada hasil belajar peserta didik sebelum menggunakan dan sesudah menggunakan media audio visual pembelajaran kisah rasul Ulul Azmi.

\section{KESIMPULAN}

Pertama media pembelajaran audio visual dinyatakan sangat baik dengan menggunakan skala penilaian menurut Artana maka media pembelajaran layak dipergunakan berdasarkan hasil belajar peserta didik pada penggunaan media audio visual dalam pembelajaran diperoleh taraf signifikansi $t$ 2,22 tabel yaitu ternyata $\mathrm{t}$ hitung lebih besar dari t tabel yaitu $3,04>2,22$.

Kedua membuktikan bahwa peserta didik mengalami peningkatan dalam hasil belajar pada sebelum menggunakan media dan sesudah menggunakan media audio visual kisah rasul Ulul Azmi. Sehingga dapat dikatakan bahwa media pembelajaran audio visual kisah rasul Ulul Azmi untuk kelas V dapat meningkatkan hasil belajar peserta didik dalam materi pokok Kisah Rasul Ulul Azmi. 
Hafidh Nur Fauzi, Istiqomah : Pengembangan Media Audio Visual Kisah Ulul Azmi Pada Mata Pelajaran Al-Islam Untuk Meningkatkan Hasil Belajar

\section{DAFTAR PUSTAKA}

A.W. Munawwir. Kamus al-Munawwir Arab-Indonesia, Surabaya: Pustaka Progressif, 1997.

Ahmad bin Ibrahim as-Samarqandi. Bahrul Ulum, CD. Maktabah Syamilah.

Ahmad Rohani. Media Instruksional Education, Jakarta: Rineka Cipta, 1997.

Alauddin Ali bin Muhammad bin Ibrahim bin Umar as-Syaihi Abu alHasan. Lubabu at-Ta'wil fi Ma'ani at-Tanzil, Beirut: Dar alFikr, 1979.

Arif S. Sadiman. Media Pendidikan Pengertian, Pengembangan dan Pemanfaatannya, Jakarta: Rajagrafindo Persada, 2011.

Artana Ketut Pegig \& Damajanti Kusuma Dewi. Evaluasi Media Pembelajaran, Surabaya: Unesa Press, 2005.

At-Thusi. Al-Tibyan, Maktabah Al-A'lam Al-Islami, 1891.

Azhar Arsyad. Media Pengajaran, Jakarta: Raja Grafindo Persada, 2002.

Beni Harsono, dkk. Perbedaan Hasil Belajar Antara Metode Ceramah Konvensional dengan Ceramah Berbantuan Media Pada Pembelajaran, Jurnal PTM, Volume 9, Nomor 2, 2009.

Benjamin Bloom S. Taxonomy of Educational: The Classification of Educational Goals, Handbook I Cognitive Domain, New York: Longman Inc Green and Co, 1956.

Borg W.R \& Gall M.D. Educational Research: An Introduction, London: Longman Inc, 2003.

Dikdasmen PP Muhammadiyah. Pendidikan Al-Islam SD Muhammadiyah Kelas V, Yogyakarta: Gramasurya, 2018.

Dimyati \& Mujiono. Belajar dan Pembelajaran, Jakarta: Rineka Cipta, 2006. 
Hafidh Nur Fauzi, Istiqomah : Pengembangan Media Audio Visual Kisah Ulul Azmi Pada Mata Pelajaran Al-Islam Untuk Meningkatkan Hasil Belajar

Fatah Syukur. Teknologi Pendidikan, Semarang: Rasail Media Group, 2008

Ibrahim Mustafa, Ahmad az-Ziyyat, dkk. Mu'jam al-Wasith: Majma' al-Lughah al-'Arabiyah bil Qahirah, Kairo: Maktabah asSyaruq ad-Dauliyah, 2005.

John W. Creswell. Research Design, Yogyakarta: Pustaka Pelajar, 2017.

Mahyuddin bin Muhammad Musthofa. I'rab Al-Qur'an wa Bayanuhu, Beirut: Dar Ibnu Katsir, 1995.

Muhammad bin Alauddin. Syarah Thawiyah, Beirut: Muassasah arRisalah, 1997.

Muhammad bin Ali bin Abdullah as-Syaukani al-Yamani. Fathul alQadir, Damaskus: Dar Ibnu Katsir, 1994.

Nana Sudjana. Penilaian Hasil Proses Belajar Mengajar, Bandung: Remaja Rosdakarya, 2009.

Nasution. Teknologi Pendidikan, Bandung: Sinar Baru, 1990.

Punaji Setyosari. Metode Penelitian Pendidikan dan Pengembangan, Jakarta: Paramedia Group. 2013.

Sugiyono. Metode Penelitian dan Pengembangan RnD, Bandung: Alfabeta, 2017.

Suharsimi Arikunto. Prosedur Penelitian: Suatu Pendekatan Praktik, Jakarta: Rineka Cipta, 2010.

Syaiful Bahri \& Aswin Zain. Strategi Belajar Mengajar, Jakarta: Ciputat Press, 2007.

Syihabbudin Ahmad bin Ahmad Umar al-Khafaji al-Mishri. Hasyi'ah as-Syi'ahab 'Ala Tafsir al-Baidhawi, Beirut: Dar Shadir, 1998.

Yudi Munadi. Media Pembelajaran, Jakarta: Referensi Group, 2013. 